\title{
Language as an Instrument of Socialization and a Representation of National Linguistic Personality
}

\author{
Baglan Bazylova ${ }^{1}$, Gulzhan Kazhigalieva1, Gulmira Kazhigaliyeva², Shynar Tazhibayeva1, \\ Zhanna Zhussupova ${ }^{3}$, Zhamal Ergalieva ${ }^{1}$ \\ ${ }^{1}$ Kazakh State Women's Teacher Training University, Almaty, Kazakhstan \\ ${ }^{2}$ Kazakh National Teacher Training University Named Abay, Almaty, Kazakhstan \\ ${ }^{3}$ K. Zhubanov Aktobe Regional State University, Aktobe, Kazakhstan \\ Email: baglan 53@mail.ru
}

Received 18 December 2014; accepted 2 January 2015; published 16 January 2015

Copyright (C) 2015 by authors and Scientific Research Publishing Inc.

This work is licensed under the Creative Commons Attribution International License (CC BY). http://creativecommons.org/licenses/by/4.0/

c) (i) Open Access

\begin{abstract}
Language, as an instrument of socialization, reveals the most important aspects of the relationship between individuals and society, while national linguistic personality reflects the characteristics of national culture and attitude. To understand a certain national personality, one must express its cultural values and specific attributes on the basis of these aforementioned aspects. In this regard, this paper examines the ideological and cultural core of the Russian and Kazakh people by focusing on certain cultural, symbolic, and stereotypical features. Comparative analysis of the Kazakh and Russian linguistic personalities shows that fundamental reforms in ideological, political, and social spheres have transformed the national linguistic personalities of both these regions.
\end{abstract}

\section{Keywords}

Socialization, National Linguistic Personality, Cultural Concepts, Lingua-Cultural Description, National Character

\section{Introduction}

The process of obtaining knowledge is based on an individual's need to expand certain aspects such as spiritual orientation, socialization, and national personality. In this regard, language acts as an instrument of socialization that increases the acquisition of knowledge and advocates an anthropocentric approach to national linguistic

\footnotetext{
*Corresponding author.
}

How to cite this paper: Bazylova, B., Kazhigalieva, G., Kazhigaliyeva, G., Tazhibayeva, S., Zhussupova, Z., \& Ergalieva, Z. (2015). Language as an Instrument of Socialization and a Representation of National Linguistic Personality. Creative Education, 6, 71-78. http://dx.doi.org/10.4236/ce.2015.61006 
personality. However, the following four definitions regarding the role of knowledge have created certain issues in the course of socialization and national linguistic personality: 1) Knowledge is fundamental to an individual's development, and all of the consequences to a certain extent are caused by knowledge. 2) The process of an individual's socialization can be considered as mastering the system of knowledge, thus raising his/her status in society. 3) The primary means of developing, maintaining, and providing knowledge is through language. 4) Finally, knowledge can be regarded as mastering the compulsory language that enables one to adequately interact with others from around the world.

In terms of modern linguistics, linguistic personality is one of the most important aspects that allow an individual to interact with others in society. The term "linguistic personality" was used for the first time by Vinogradov in the book "About Art Prose" (1930) in which his idea of language assumed that a person with linguistic intelligence possesses an inherent gift for words (Vinogradov, 1930). Meanwhile, von Humboldt considered that language is the indicator of both people and a nation's spirit, and linguistic personality is a representative of Homo sapiens and a concrete nation (Humboldt, 1984). Furthermore, Shakhmatov stated that "language differentiates human beings from other living things...” (Shakhmatov, 1936) and Karaulov distinguished three levels of linguistic personality: verbal and semantic, cognitive, and motivational (Karaulov, 1987).

In general, the term "linguistic personality” in linguistic literature has been interpreted as follows:

-“A person proving himself in speech activity, possessing a set of knowledge and ideas” (Krasnykh, 2000). -A generalized image as a bearer of cultural and language, communicative and activity values, knowledge, installations and behavioral reactions (Karasik, 2004).

-A person having the ability to create and perceive texts, which differ in: "1) degree of structural and language complexity; 2) profundity and accuracy of reality reflection; 3) certain target orientation” (Karaulov, 1987).

National linguistic personality is a multicomponent concept that includes an individual's psychophysical properties, verbal behavior features, and communicative abilities. According to Vorobyev, when studying national linguistic personality, it is necessary to consider three overall aspects: 1) spirituality (moral and ethical); 2) material and cultural "context" in its lingua-cultural comprehension (communication with others); and 3) historical development of integrity and invariancy (Vorobev, 2008). Karaulov stated that there was the "necessity for an integrated approach to its analysis, an opportunity for and need of revealing not only its psychological features but also philosophical and world outlook preconditions, ethno-national features, social characteristics, and historical and cultural sources” (Karaulov, 1989).

When mastering the mother tongue, there is a gradual but intensive transformation of genetic language (the basic rules of genetic texts) into an individualized version of a certain ethnic language. Thus, one of the most important aspects of linguistic personality is defining the typical national markers. In our opinion, when forming the list of national markers, it is necessary to begin by focusing on the various stereotypes of national character. For example, such characteristics for Russians include bold, Russian soul, unpredictability, and carelessness, while Kazakhs are represented by hospitality, outspokenness, tolerance, fighting spirit, and leaning toward family relations. Revealing these features of the Russian and Kazakh people supports the following:

-Peaceful co-existence of representatives of different cultures (knowledge leads to comprehension).

-Adequate interpretation of works of art written in the Russian and Kazakh languages.

-Polycultural dialog.

-Maintenance of respect for national traditions and customs.

The aforementioned representation of the Russian national personality is an example of a complex, linguacultural description of national personality offered by Vorobyov in his work "Linguaculturology" (2008). The core and group paradigmatic and syntagmatic attitudes of Russian linguistic words represent national and cultural characteristics as well as basic symbols of Russian culture (Vorobev, 2008).

Regarding the Kazakh linguistic personality, there are numerous works in which various concepts in the Russian and Kazakh languages (Dosimova, 2008; Ananina, 2006) as well as bilingualism of Russian-Kazakh art (Kazhigaliyeva, 2001; Girutsky, 2007; Chasanov, 1990; Chenki, 1996; Chafe, 1994) have been compared. However, no lingua-cultural research on the Kazakh linguistic personality exists. Therefore, this study examines the Kazakh linguistic personality and focuses on its pertinent ideological and cultural aspects (Zamilova, 2013; Hachmafova \& Makerova, 2010). 


\section{Materials and Methods}

Based on our principal component analysis, lingua-cultural method, and associative experiment, we defined the Kazakh national personality after comparing the features of the Russian and Kazakh linguistic personalities. Component analysis was employed to identify the semantic structure of the considered concepts while the lingua-cultural method helped define the cultural differences and ideological aspects found in the Kazakh and Russian linguistic personalities. Furthermore, through the associative experiment, which is widely utilized in psycholinguistics, basic linguistic words representing national, cultural, and peripheral components of the language group were defined. Finally, conceptual analysis enabled revealing the lingua-cultural concepts of the Russian and Kazakh linguistic personalities and comparing them with national and cultural connotations.

\section{Results and Discussion}

Table 1 presents the two lingua-cultural groups for comparison: the "Russian linguistic personality" based on Vorobyov and our "Kazakh linguistic personality”. By examining these lingua-cultural groups, one can determine their paradigmatic and syntagmatic relations.

According to Table 1, linguistic words such as dzhigit in the "Kazakh linguistic personality" are associated with the following concepts: love of freedom, bravery, strength, courage, dexterity, horse, nobility, honor, and art. In syntagma, the relations are presented by proverbs:

-Dzhigit is a well-known name.

-Dzhigit is known as trouble in horse racing.

-A long and difficult journey: a test of Dzhigit.

-For Dzhigit, it is better to die than to promise twice.

-Dzhigit is a word told to protect people.

-Dzhigit never promises in vain and never goes back on his word.

-The real Dzhigit is recognized even in a shepherd's cloak.

-Dzhigit is a mirror of his people.

-A lion will be conquered by the Dzhigit with a lion's heart.

-Dzhigit must be a burning fire, if not, he is not a Dzhigit.

Dzhigit, a linguaculturema (a linguistic word that represents a national or cultural peculiarity), is closely connected with the concept of honor (намыс). In the Kazakh and Russian linguistic personalities, this concept is extremely valued. A loss of honor (dishonor) in both Russian and Kazakh cultures is worse than death, which is confirmed by the following proverbs:

Russian proverbs:

Table 1. Comparison of Russian and Kazakh linguistic personalities.

\begin{tabular}{|c|c|}
\hline Russian linguistic personality & Kazakh linguistic personality \\
\hline \multicolumn{2}{|c|}{ Gist } \\
\hline Russian man, Russian woman, great Russians & Kazakh man, Kazakh woman, nomad \\
\hline \multicolumn{2}{|c|}{ Center } \\
\hline $\begin{array}{l}\text { Russian character, Russian beauty, Russian mind, Rusist (specialist in } \\
\text { Russian philology), Russism, the Russian language is the language of } \\
\text { international communication of the CIS, Russian-speaking, Slavophil; } \\
\text { material culture: kvass, medovukha (strong drink made from honey), } \\
\text { pancakes, Russian cabbage soup, porridge, kvass, kosovorotka (man's } \\
\text { blouse), khorovod (round dance), cap with ear-flaps, balalaika, etc. }\end{array}$ & $\begin{array}{l}\text { dzhigit, Kazakh batyr, love of freedom, Kazakh hospitality, } \\
\text { tor (place of honor), dastarkhan, zheti kazyna, family tree } \\
\text { (zheti ata); Kazakh language, nomad, turk, zhuz, chingizid } \\
\text { (descendants of Chingiz khan), argamak, akyn, biy, oratory, } \\
\text { cattle breeding, dzhailay, steppe, baiga, kyz-kuu; } \\
\text { material culture: Kazakh ornament, yurta, felt, Kazakh meat, } \\
\text { koumiss, chapan, dombra, shubat, kobyz, etc. }\end{array}$ \\
\hline
\end{tabular}

Periphery (classes of linguistic words meaning national, cultural peculiarities, being crossed with closely related groups)

Slavic language, Slavic studies, bolshevik, bolshevism, soviet, muscovite, a native of the Volga region.
Turkic language, turkology, Alash-orda, almaatinets (resident of Almaty city), astanchanin (resident of Astana city), kazakhstanets (citizen of Kazakhstan), virgin land. 
-The head is perished for honor; honor is preserved by the head.

-Take away my good name, and take away my life.

-A bad wound is cured, not a bad name.

-Honor is appreciated not by words but by awards.

-A good name is better than riches.

-Dishonor is worse than death.

-Give a whipping but don't deprive honor.

-Death is not as terrible as shame.

Kazakh proverbs:

-Ерді намыс өлтірер, құоянды қ̧амыс өлтірер (Pride apes humility).

-Ер жігітке өлімнен ұят күшті (For Dzhigit, disgrace is worse than death).

-Өлімнен ұят күшті (Shame is greater than death).

In regard to honor and pride, the following Kazakh paremiyas (set expressions) show how Dzhigit is representative of the peoples' conscience and overall pride:

- Жігіттің құны жүз жылқы, ары мың жылқы. (Dzhigit is worth one hundred horses, so the value of his honor is one thousand horses).

- Ел намысы, ер намысыл. (The honor of the people is the honor of Dzhigit).

- Ер жігіт елінің ұлы, намыссының құлыл. (Dzhigit is the son of his people and the slave of his conscience).

- Атты құамшы айдайды, ерді намыс айдайды. (A horse is lashed with a whip while Dzhigit is lashed with his honor).

- Жақссы аттың жалын сақтаванша, жақсы жіzіттің арын сақта. (It's better to take care of Dzhigit’s honor than a racer's strength).

The spiritual value of honor and pride for both the Russian and Kazakh people can also be found in following excerpts from literature:

Be reasonable, strengthen the spirit in fight.

Only the ungifted obeys destiny... (Abay)

Respect for the poet is honor for the people.

Poetry enriches life as it is.

Let akinak (iron sword) pierce the chest,

Ennoble your soul while praising to the skies. (Shakarim)

Hide, the clay city!... Die, my mother!...

Grandfather, end the long life, don't torment,

while you are honest, fly in the sky with an arrow.

Wives, wives, throw your children from the wall!

Drink poison! Have a shower bath with boiling pitch! (Suleymenov)

A poet died! - the slave of honor-

He fell slandered by a rumor,

With lead in his chest and a thirst for revenge,

Having hung the proud head! (Lermontov)

Oh, God, alleviate our grief,

Far from anger, pain and revenge,

And tear s-silent early morning dew-

for him, murdered in the field of honor.

Is the candle lit by you thawing?

Accept what is there on earth and as to the bride,

Open your lightened fields

To the murdered soul in the field of honor. (Gippius)

One cannot have honor hundred times.

It is alone. And after defeat

You cannot patch it like a jacket,

Or take it to dry—cleaning on Sunday! (Asadov) 
The next linguaculturema, Kazakh hospitality, is seen in words such as төp (place of honor), dastarkhan, meat, lamb, ram, head, guest, Kazakh meat, koumiss, bata (blessing), and chapan as well as the following Kazakh proverbs:

-A house where there are no guests is similar to a grave.

-One can say "come in" to a guest, but it is impossible to say "go away".

-When a guest arrives, the meat should be cooked. If there is no meat, then the host burns with shame.

-The threshold is not a place for the guest of honor.

Kazakh hospitality is also seen in the following expressions:

At mingizip shapan zhabu-An honored guest or respected person is presented with a horse and a shapan. This custom still exists today.

Bata-This blessing, in the form of laconic poetry, is given by elders (aksakals) before a long and arduous journey.

Bel koterer-A custom in which elderly people are regaled with delicious fare made of kasy, butter, zhent, koumiss, cottage cheese, honey, etc. It is usually prepared by children, neighbors, and relatives in respect of their elders.

Erulik-A tradition in which new settlers are presented with certain necessities by their neighbors as an act of kindness and hospitality.

Konakasy (konak (guest); asy (regale))—The act of welcoming a guest with honor by regaling him/her with tasty treats. For Kazakhs, guests are divided into three overall types: arnayy konak (a specially invited guest); kudayy konak (a casual traveler); and kydyrma konak (an unexpected guest). When a person did not give konakasy, he/she was fined (the penalty was usually a horse, camel, or some other livestock).

Konak kade (konak (guest); kade (a gift))—A custom in which a host asks the guest to make konak kade, that is to sing a song, recite a poem, etc. Since early times, Kazakhs have taught their children to play musical instruments, sing, compose verses, etc. Konak kade is both a test of a guest's talents as a well as a pledge of enjoying a cheerful feast.

Dastarkhan, another linguaculturema, includes an important symbolic value. It not only reflects Kazakh hospitality but also the essence of showing respect to the guest by presenting certain talents (musical, poetic, etc.). This can be seen in the following proverbs:

Ac-адамның арқ̧aybl: (Food always gives strength to people).

Дам тартқан қүдызына түкірме: (Never spit in the same well of which you sometimes drink).

Acы бар аяқтан аттама: (Don't step over a dish with food. Show respect to the person who prepared it).

Em-етке, сорпа-бетке: (Everything is done in its season).

Әкесі тірі адам төрге шықпайды, бас ұстамайды (The person whose father is alive does not sit in the seat of honor and participate in the carving of the ritual dish).

In regard to Russian linguaculturema, syntagmatic relations are expressed through the following Russian proverbs and sayings:

-Practice makes perfect.

-If spruce and pine are the same firewood, then fritters and pancakes are the same food.

-A drink is shorter than a tale.

-Time is required to cook pancakes.

-As dough rises, a pie is baked; as a pie is baked, a pancake is made; if the pancake is ready, then everyone can eat it (i.e., one action is followed by another).

To reveal the primary differences between the two linguacultural groups, Table 2 compares the paradigmatic and syntagmatic relations of each language.

According to Table 2, the linguaculturema motherland presents culturological differences. From the Russian perspective, motherland is associated with feminine beginnings (i.e., the motherland is Moscow). Conversely, in the Kazakh language, atameken is associated with the concept or aruakhi (ancestors' spirits) and any aspect of significant importance related to geneology. In regard to Great Russian, from the Russian perspective, it signifies historical greatness of the nation and its tsar-imperial past. For Kazakh, it is derived from the Turkish khassak, which means free, freedom-loving, brave, and courageous. Another version of kazak is translated from 
Table 2. Comparison of paradigmatic and syntagmatic relations in Russian and Kazakh linguistic personalities.

\begin{tabular}{|c|c|}
\hline Russian linguistic personality & Kazakh linguistic personality \\
\hline $\begin{array}{l}\text { 1. Motherland: } \\
\text { fatherland, Moscow, first-throned, Kiev Rus, } \\
\text { white stoned, motherland } \\
\text { - I wish to live and die in Paris if there is no } \\
\text { such earth as in Moscow. } \\
\text { - For the motherland (a war-call). }\end{array}$ & $\begin{array}{l}\text { 1. Atameken: } \\
\text { earth of fathers (ancestors), Holy Land, patrimonial cemeteries } \\
\text { - It is better to be a slave in the motherland than a sultan on foreign soil. (a man's } \\
\text { home is his castle). } \\
\text { - Aruakh (spirits of ancestors_-a war-call). }\end{array}$ \\
\hline $\begin{array}{l}\text { 2. Etnonim } \\
\text { Russian: Great Russian. }\end{array}$ & $\begin{array}{l}\text { 2. Etnonim } \\
\text { Kazakh: free, swan (beauty and grace)—be a Kazakh (strong, } \\
\text { courageous_-expression-wish at the Georgians). }\end{array}$ \\
\hline $\begin{array}{l}\text { 3. Government power (form of government). } \\
\text { Tsar-father, emperor, the father of ours } \\
\text { (wisdom, justice, fatherlike care). }\end{array}$ & $\begin{array}{l}\text { 3. Government power (form of government). } \\
\text { Horde, khan, sultan, Biy (intellect, wisdom, oratory, justice, honesty). }\end{array}$ \\
\hline $\begin{array}{l}\text { 4. Spiritual feature (character). } \\
\text { Brave, courageous, strong, frank, hospitable, } \\
\text { careless. } \\
\text { - Bread and salt are the main things for a } \\
\text { Russian man. } \\
\text { - A Russian man is a kind man. } \\
\text { - A Russian man likes to do everything at } \\
\text { random. }\end{array}$ & $\begin{array}{l}\text { 4. Spiritual feature (character). } \\
\text { Brave, freedom-loving, generous, frank, faithful, hospitable, conceited, respecting } \\
\text { elderly people. } \\
\text { - } \quad \text { If a Kazakh is your friend, then you won't get lost (Uzbek proverb); } \\
\text { - Ер жігіттің екі айтқаны-өлгенмен тен (For Dzhigit, it’s better to die than to } \\
\text { promise twice); } \\
\text { - } \quad \text { Құтты қонаққа-тәтті тамақ (an honorable feast for the guest of honor); } \\
\text { Сыйлап берсе-суын іш (Water is also food if given with heart and soul); } \\
\text { - aksakal (a respected elder) } \\
\text { - } \quad \text { жарыктык—-respectful attitude toward elders; } \\
\text { - } \quad \text { кыз жибек (a young girl)—respectful attitude for women. }\end{array}$ \\
\hline $\begin{array}{l}\text { 5. Material culture: } \\
\text { 1) izba (log hut) (tree); } \\
\text { 2) sarafan (sundress) (flax); } \\
\text { 3) cuisine (bread, pancakes, pies, } \\
\text { porridge)_simplicity. }\end{array}$ & $\begin{array}{l}\text { 5. Material culture: } \\
\text { 1) yurta (wool); } \\
\text { 2) chapan (velvet); } \\
\text { 3) cuisine (meat: kazy, zhaya, zhal; milk products: koumiss, ayran, shubat)—caloric } \\
\text { content, simplicity, healing properties. }\end{array}$ \\
\hline
\end{tabular}

two words: қ̧aз $+a k$ (white goose or swan). However, most Kazakh representatives relate to the first version since it is more plausible.

Certain differences are also shown through a comparison of the forms of government. Despite the fact that both Kazakhstan and Russia included a long history of monarchies, their stereotypic ideas of government differ. From the Kazakh perspective, the khan was required to be not only wise and fair but also have oratorical skills, which were greatly appreciated by the Kazakh people. In this regard, poets in Kazakh society were highly respected for their art. These poets were also known for being courageous since they were not afraid of being truthful to the khan. For example, when Zhangir Khan asked Makhambet Utemisov, "Do you doubt that I am fair?” he answered with the following verses:

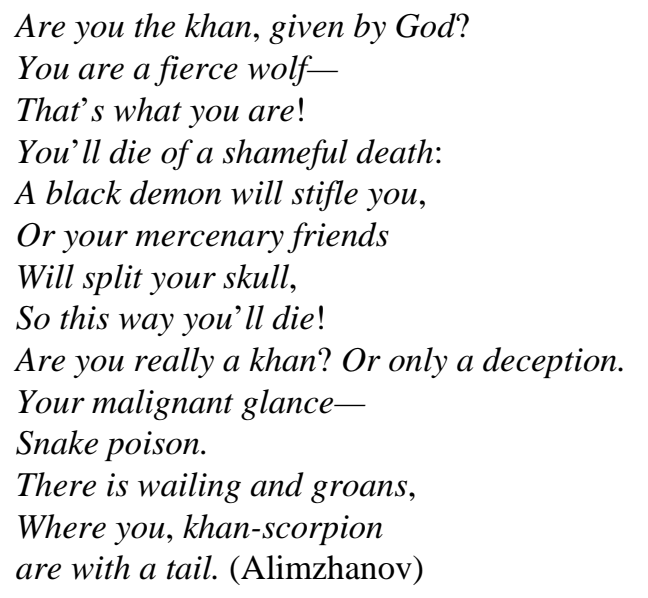

Additional examples of the poet's strength through words include the following: 
Your old friend will never be an enemy to you,

As his blood was admixed with yours during an oath...

And an old enemy never becomes a true friend,

Because his blood is spilled by your hand! (Esenberlin)

There, where the power generates only cruelty,

Wisdom is hidden in fear, my khan...

No, not for good you sacrifice batyr

For your feelings... (Esenberlin)

In the $19^{\text {th }}$ and early $20^{\text {th }}$ centuries, there were expressions that protested and criticized those in power, as seen in the following two excerpts taken from poetry and a song:

Allah doesn't forgive any evil

Who creates strife and hostility in hearts;

The grandfather quarreled with a large clan... (Auezov)

From the Karatau's tops nomads are going...

Behind every caravan there is a lonely camel...

There is no more serious grief than to lose the family, the native earth

You won't be able to keep back tears - they flow, flow... (Alimzhanov)

The social importance of personality is of particular interest to linguacultural comparison. From the Kazakh perspective, origin, genealogy, and family are extremely important and considered as obligatory. In addition, service to one's family is considered a great honor. Therefore, the use of the paradigm shezhire includes concepts such as honor, dignity, courage, force, tamga, aul, collectivism, martial spirit, the earth of a clan, and $a k-$ sakals (elders).

In sum, the most significant symbols for both the Russian and Kazakh cultures include the following:

-Motherland.

-Morality.

-Origin, history of nation.

-Religion.

-Main sphere of economic activity.

-Climate and geography.

-Art.

-Material culture (ethnographic realm (national, folk phenomenon)).

In regard to the Russian culture, the basic symbols include the following:

- Religion: cross - a symbol of Christian religion, suffering, purification.

- Main sphere of economic activity: bread—a symbol of well being, Russian hospitality.

- Main sphere of economic activity: pancake—a symbol of abundance, well being.

- Climate and geography: birch—a symbol of Russia, grief, sufferings.

- Climate and geography: bear-a symbol of Russia, Russian man (big, lazy, clumsy, strong, terrible in anger, but good natured).

- Material culture (ethnographic (national, folk phenomenon): matreshka-a symbol of unexpectedness, surprise.

- Material culture (ethnographic (national, folk phenomenon): samovar-a symbol of home comfort and family well being.

In regard to the Kazakh culture, the basic symbols include the following:

- Main sphere of economic activity, material, and spiritual culture: horse (racer)—nobility, beauty, devotion, freedom.

- Main sphere of economic activity: meat—a symbol of welfare, wealth, hospitality.

- Religion: aruak — symbolizes the belief of Kazakhs and their ancestors' spirits.

- Main sphere of economic activity: koumiss — symbol of purity (white blessing), health, force, equilibrium of corporeal and mental strength.

- Morality and spiritual culture: batyr — symbol of bravery, courage, nobility, justice, and fortitude). 
- Origin and history of the nation: zheti ata (clan, zhuz)—symbolizes knowledge, one's history, and family tree.

- Material culture (ethnographic (national, folk phenomenon)): shanyrak—being the main part of a yurta, its form is reminiscent of a heavenly dome or an arch of heaven (peace and tranquillity). It is the symbol of life- the sun, home, unity, and well being.

- Art: dombra — symbolizes the most important part of Kazakhs’ spiritual culture-their love of music and art.

\section{Conclusion}

This study examined how aspects of the Russian and Kazakh languages were instruments of socialization and valuable representatives of their national linguistic personalities. Through comparative linguacultural analysis, it was determined that the main values, symbols, and stereotypes of Russian and Kazakh linguistic personalities were defined by social and economic organization, culture, and traditions. In addition, fundamental reforms in ideological, political, and social spheres had transformed the national linguistic personality of both these regions.

\section{References}

Ananina, T. V. (2006). Emotions and Language Picture of the World. Messenger of KASU, 2, 92-99.

Chafe, W. (1994). Discourse, Consciousness and Time. The Flow and Displacement of Conscious Experience in Speaking and Writing. Chicago: Univ. Chicago of Press.

Chasanov, B. (1990). Kazakh-Russian Literary Bilingualism. Almaty: Rauan.

Chenki, A. (1996). Modern Cognitive Approaches to Semantics of Similarities and Differeces in Theories and Goals. Problems of Linguistics, 2, 68-78.

Dosimova, M. S. (2008). National Specifics of Language Objectivization of a Concept "Woman": On the Material of the Russian and Kazakh Languages. Candidate of Philological Sciences, Thesis, Astrakhan: Astrakhan University.

Girutsky, A. A. (2007). Beloruss-Russian Art Bilingualism: Typology and History, Language Processes. Minsk: High School.

Hachmafova, Z. R., \& Makerova, S. R. (2010). Cognitive Systems of Linguistic Identity in the Process of Interpretation of a Literary Text. Herald MGOU, 1, 51-56.

Humboldt, V. (1984). Selected Works on Linguistics. Translation from German, Moscow: Progress.

Karasik, V. I. (2004). Language Circle: Person, Concepts, Discourse. Moscow: Gnozis.

Karaulov, Yu. N. (1987). Russian Language and Linguistic Personality. Moscow: Science.

Karaulov, Yu. N. (1989). Russian Linguistic Personality and Problems of Its Studying. Moscow: Nauka Publ.

Kazhigaliyeva, G. A. (2001). Linguacultural Aspect in Work on the Art Text. Almaty: Codex.

Krasnykh, V. V. (2000). Language, Consciousness, Communication. In V. V. Krasnykh, \& A. I. Izotov (Eds.), Collection of Articles (pp. 41-51). Moscow: Dialogue Moscow State University.

Shakhmatov, A. A. (1936). Sketch of Modern Russian Literary Language (12th ed.). Moscow: Learning and Teaching Publishing.

Vinogradov, V. V. (1930). About Art Prose. Moscow: Science, 24-33.

Vorobev, V. V. (2008). Linguaculturology. Moscow: Publisher of the Russian Peoples' Friendship University.

Zamilova, A. V. (2013). Lingvosocionic Modeling of Russian Language Personality (Based on Online Blog). Thesis, Kemerovo: Kemerovo University. 
Scientific Research Publishing (SCIRP) is one of the largest Open Access journal publishers. It is currently publishing more than 200 open access, online, peer-reviewed journals covering a wide range of academic disciplines. SCIRP serves the worldwide academic communities and contributes to the progress and application of science with its publication.

Other selected journals from SCIRP are listed as below. Submit your manuscript to us via either submit@scirp.org or Online Submission Portal.
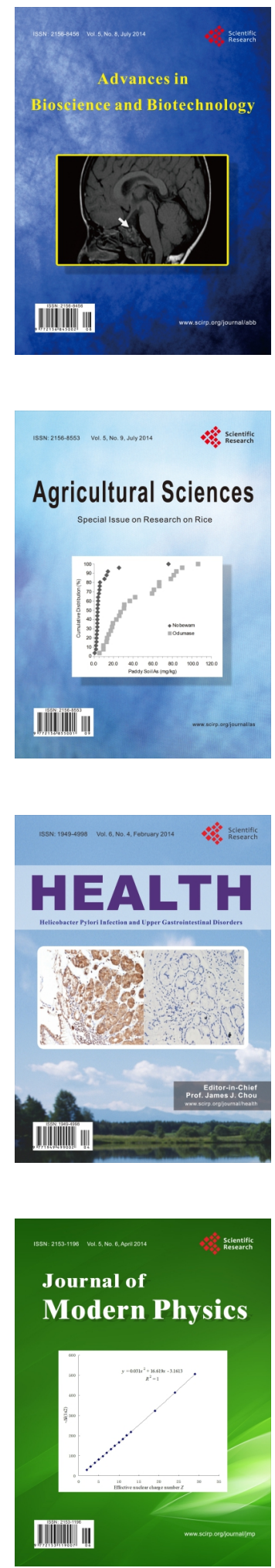
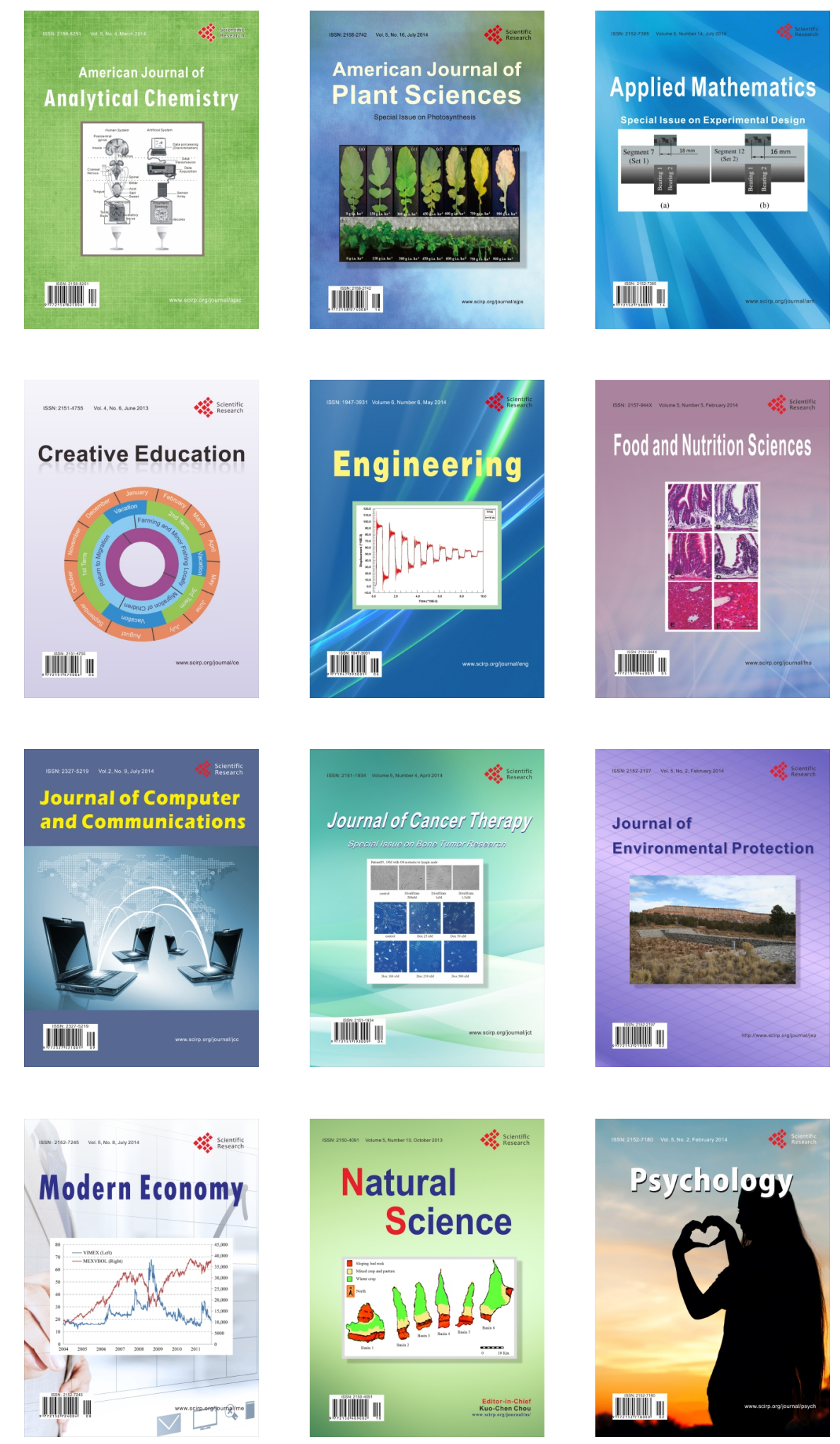